\title{
"Gringo panic": estrangeiros predadores, eventos esportivos globais e prostituição no Rio de Janeiro
}

\author{
“Gringo panic": predatory foreigners, global sports \\ events and prostitution in Rio de Janeiro
}

\author{
Gregory Mitchella
}

\section{Tradução de Tiago de Aquino Tamborino ${ }^{b}$}

Resumo Durante a preparação para a Copa do Mundo de 2014, setores da mídia, ONGs e o Estado contribuíram para criar um pânico crescente sobre a prostituição. Incursões policiais violentas em locais lícitos de comércio sexual aumentaram e a polícia convidou a imprensa para transmitir o fechamento do local de turismo sexual de maior visibilidade no dia da abertura da Copa. Na verdade, a prostituição não aumentou no Rio de Janeiro e não houve casos confirmados de tráfico sexual associados ao evento na cidade. A "limpeza" das zonas de prostituição foi uma apropriação das terras com o objetivo de promover a limpeza social e a "renovação urbana" em Copacabana (Rio de Janeiro). Este artigo analisa como atores estatais e não-estatais construíram imagens de "gringos" - frequentemente como invasores predatórios -, criando um pânico moral para promover suas próprias agendas. Baseando-se em trabalho de campo etnográfico realizado com profissionais do sexo e clientes antes, durante e depois da Copa, a pesquisa analisa as fantasias projetadas sobre os "gringos" por vários atores - profissionais do sexo, setores da mídia, cristãos evangélicos e feministas, entre outros. Argumenta-se que os clientes "gringos" durante a Copa podem ser entendidos como turistas sexuais atípicos, que possuem uma agência limitada e que vivenciaram diferenças importantes no capital social e na competência cultural. A crença nas ideias preconcebidas sobre a masculinidade do "gringo" gerou consequências sociais imprevistas, incluindo a marginalização ainda maior das mulheres vulneráveis que trabalham na economia sexual do Rio.

Palavras-chave gringos; prostituição; Copa do Mundo; pânicos sexuais.

Abstract In the run-up to the 2014 World Cup, sectors of the media, NGOs, and the state contributed to a growing panic about prostitution. Violent police raids on legal

a Professor de estudos sobre mulheres, gênero e sexualidade na Williams College, Estados Unidos.

b Mestre pelo Instituto Nacional de Saúde da Mulher, da Criança e do Adolescente Fernandes Figueira - Fundação Oswaldo Cruz. 
commercial sex venues increased and police invited the media to broadcast them closing the most visible sexual tourist venue on the opening day of the Cup. In truth, prostitution did not increase in Rio de Janeiro and there were no proven instances of sex trafficking linked to the event in that city. The "clean-up" of red light districts was a land grab aimed at social cleansing and "urban renewal" in Copacabana (Rio de Janeiro). This paper examines how state and non-state actors constructed images of gringos - often as predatory interlopers - to create a moral panic in order to further their own agendas. Drawing on ethnographic fieldwork conducted among sex workers and clients before, during and after the Cup, this research examines the fantasies projected onto gringos by various constituents - sexworkers, media sectors, evangelical Christians, feminists, and others. It argues that gringo clients during the Cup are best understood as atypical sex tourists with diminished agency who experienced key differences in social capital and cultural competency. The reliance on misinformed ideas of gringo masculinity has unintended social consequences, including the further marginalization of vulnerable women working in Rio's sexual economy.

Keywords gringos; prostitution; World Cup; sexual panics.

\section{INTRODUÇÃO: PARA INGLÊS VER ${ }^{1}$}

A polícia militar chegou ao Balcony Bar em Copacabana na manhã do dia da cerimônia de abertura da Copa do Mundo de 2014. Com a PMRJ vieram as câmeras do jornal $O$ Globo. O Balcony Bar era considerado um bar e restaurante infame da orla, onde "gringos" podiam encontrar prostitutas, antes de levá-las para fazer programas em outros locais. Contudo, a prostituição não é ilegal no Brasil e, sendo assim, as prostitutas que trabalham naquela área têm o direito de frequentar qualquer bar ou estabelecimento que elas queiram, desde que não perturbem a paz. Em dias de semana, poderíamos encontrar algumas dezenas de mulheres trabalhando no local e, nos finais de semana, era possível encontrar 100 ou mais mulheres na parte interna, no pátio ou em pé, na parte de fora do Balcony. O Balcony era um estabelecimento familiar durante o dia, porém por volta das $22 \mathrm{~h}$ as prostitutas começavam a chegar. O Bar lucrava com a prostituição apenas indiretamente, ao vender comida e bebida para os clientes. Infelizmente, o Balcony estava localizado em frente à área onde foi realizada a FIFA Fan Fest na praia de

1 Este artigo é baseado no trabalho apoiado pela National Science Foundation, registro número 1450870. Quaisquer opiniões, resultados e conclusões ou recomendações aqui são de responsabilidade do autor e não refletem necessariamente as opiniões da Nacional Science Foundation. 
Copacabana e, portanto, na área do Rio mais visada pelos jornalistas durante a Copa do Mundo. O Balcony e suas centenas de clientes e prostitutas estavam no coração das festividades da Copa. O Balcony e as mulheres que vendem serviços sexuais estavam entusiasmados com essa localização, imaginando que isso seria ótimo para os negócios. Eles estavam enganados.

No primeiro dia da Copa, a polícia fechou o Balcony Bar, pendurando na porta um cartaz que dizia que todas as atividades econômicas daquele estabelecimento tinham sido suspensas, pois ali havia o "incentivo à exploração sexual de vulneráveis" (é importante ressaltar que nunca houve qualquer acusação formal ou condenação. Diante de infinitas e onerosas batalhas jurídicas, o proprietário finalmente parou de lutar). Naquela noite, fui com alguns colegas para observar o que poderia acontecer quando as mulheres fossem trabalhar, mas encontramos o bar fechado. Os clientes foram lá também. As pessoas começaram a cantar alegremente - “Abre! Abre! Abre!”. Eles sorriam e permaneciam próximos ao Balcony Bar. Alguém colou no emblema policial um adesivo que dizia: "FUCK FIFA" (FODA-SE A FIFA). Naquela noite, cerca de 200 garotas de programa e 200 clientes festejaram na Praça do Lido, que fica ao lado do Balcony Bar. As prostitutas ${ }^{2}$ mantiveram-se perto o bastante do bar para usar o sinal de Wi-Fi. Ambulantes aproveitaram a oportunidade para vender bebidas e lanches.

Naquela noite, percebi que havia três garotas que permaneciam entre os carros, nas proximidades do evento, e me parecia que elas eram claramente menores de idade. Essa era a grande ironia da incursão policial. Até então, nunca havia tido garotas menores de idade no Balcony. Meus colegas e eu estivemos lá centenas de noites fazendo trabalho de campo, e nunca presenciamos um único caso de menor trabalhando no local ${ }^{3}$. Em raras ocasiões poderia haver adolescentes trabalhando nas redondezas, nas ruas, na praia, porém não no Balcony. Em 2012, O Globo fez uma reportagem onde duas menores de idade (de 16 e 17 anos), que falsificaram identidades, estavam trabalhando no local. De forma sensacionalista, O Globo fez

2 No Brasil, as prostitutas dos movimentos dos direitos das prostitutas (incluindo grupos como Davida) preferem o termo prostituta à "profissional do sexo". No entanto, profissional do sexo também pode se referir a uma gama mais ampla de profissionais dentro de uma economia sexual. Portanto, eu tendo a usar o termo prostituta, a menos que me refira a esta categoria de forma mais ampla.

3 Sou grato aos meus colegas do Observatório da Prostituição, especialmente Ana Paula da Silva, Julie Ruvolo, Yaa Saarpong, Lucas Dias, Gonçalo Zúquete, Laura Murray, Soraya Simões, Flavio Lenz e Amanda de Lisio. Também devo agradecer a João Sodré por suas contribuições para a minha compreensão das situações políticas, econômicas e jurídicas. Sou especialmente grato a Thaddeus Blanchette. Embora Blanchette não apareça como coautor deste artigo, os leitores devem estar cientes de que ele estava ativamente envolvido em quase todas as observações de campo descritas e contribuiu muito para a minha compreensão sobre o assunto. 
parecer que o Balcony Bar era um antro de prostituição infantil e que precisava ser fechado imediatamente. Dois anos mais tarde, na manhã do dia da cerimônia de abertura da Copa do Mundo, O Globo estava lá para filmar a incursão final que fechou o local. Na verdade, os gerentes estavam sempre atentos para manter tais garotas fora do local - e assim também faziam as mulheres que trabalhavam lá, não por instinto maternal, mas por interesse capitalista. Elas esbravejavam raivosamente para as meninas, gritando que elas fossem "se foder" em outro local que não fosse aquele ponto privado em frente à praia. Agora, algumas horas após o fechamento do Balcony, aquelas adolescentes podiam trabalhar no mercado sexual da Praça do Lido onde mulheres de todas as idades estavam trabalhando.

Durante a Copa, percebi que em todas as noites havia quase sempre três ou quatro adolescentes trabalhando na rua entre os foliões na Praça do Lido. Elas geralmente não se posicionavam na área central, mas sim entre os carros estacionados, pois lá ficavam menos visíveis. As mulheres mais velhas, ao contrário disso, optavam pela máxima visibilidade na área principal da praça. Outros pesquisadores perceberam o mesmo e pudemos registrar que havia sempre alguns homens estrangeiros que iam conversar e logo em seguida saíam do local com aquelas adolescentes, presumivelmente para fazer programas. Para ser claro, seria uma interpretação grosseira desses dados, dizer que a Copa do Mundo causou um aumento significativo da prostituição de menores no Rio de Janeiro. Entretanto, o fechamento do Balcony Bar, de um hotel e eventualmente de alguns outros clubes conhecidos por facilitar a prostituição naquela área, certamente coincidiu com o aparecimento ou a realocação de um pequeno grupo de adolescentes que começaram a se prostituir naquela área. Não havia essa possibilidade antes do fechamento do bar. É importante salientar que as garotas em questão não eram pré-adolescentes. Outras pesquisas são necessárias para concluir se essa prostituição de menores de idade foi uma redistribuição laboral que simplesmente fez com que garotas que já trabalhavam em outros locais do Rio ficassem mais visíveis, mas o que fica claro é que, se o comércio sexual tivesse sido legalmente permitido no Balcony Bar, teria sido muito difícil para as garotas trabalharem naquela área da orla, com fácil acesso aos turistas da Copa do Mundo.

O comércio sexual também se estendeu por alguns quarteirões e se reconcentrou em um local parecido com o Balcony, chamado Mab's, e que efetivamente se tornou o novo Balcony Bar. Existem inúmeros locais nas ruas paralelas a partir da Praça do Lido que continuaram a prosperar e tiveram a sorte de não estar muito próximos ao FIFA Fan Fest. A polícia estava por toda orla naquela noite, "mantendo a paz" caso alguém fosse roubado ou causasse alguma confusão. Mais 
de 50 policiais estavam próximos à Praça do Lido, onde as prostitutas trabalhavam, perto do Balcony Bar, que se encontrava fechado. Alguns destes policiais estavam apenas a alguns metros das meninas menores de idade descritas anteriormente e até mesmo trocavam olhares com elas. Eu, pessoalmente, observei turistas sexuais perguntarem a esses policias por informações sobre o comércio sexual nas redondezas e ouvi a polícia indicar o Barbarella, um local que (como descrevo abaixo) também esteve sujeito a incursões policiais antes da Copa do Mundo. Apesar de tudo, a polícia fechou o Balcony por encorajar a exploração sexual, ainda naquela manhã. A polícia não tinha mais nenhum interesse naquelas mulheres ou meninas que vendiam sexo diante dos seus olhos. A exploração sexual não importava. $O$ Globo e suas câmeras que estiveram ao seu lado naquela manhã não estavam mais entre eles.

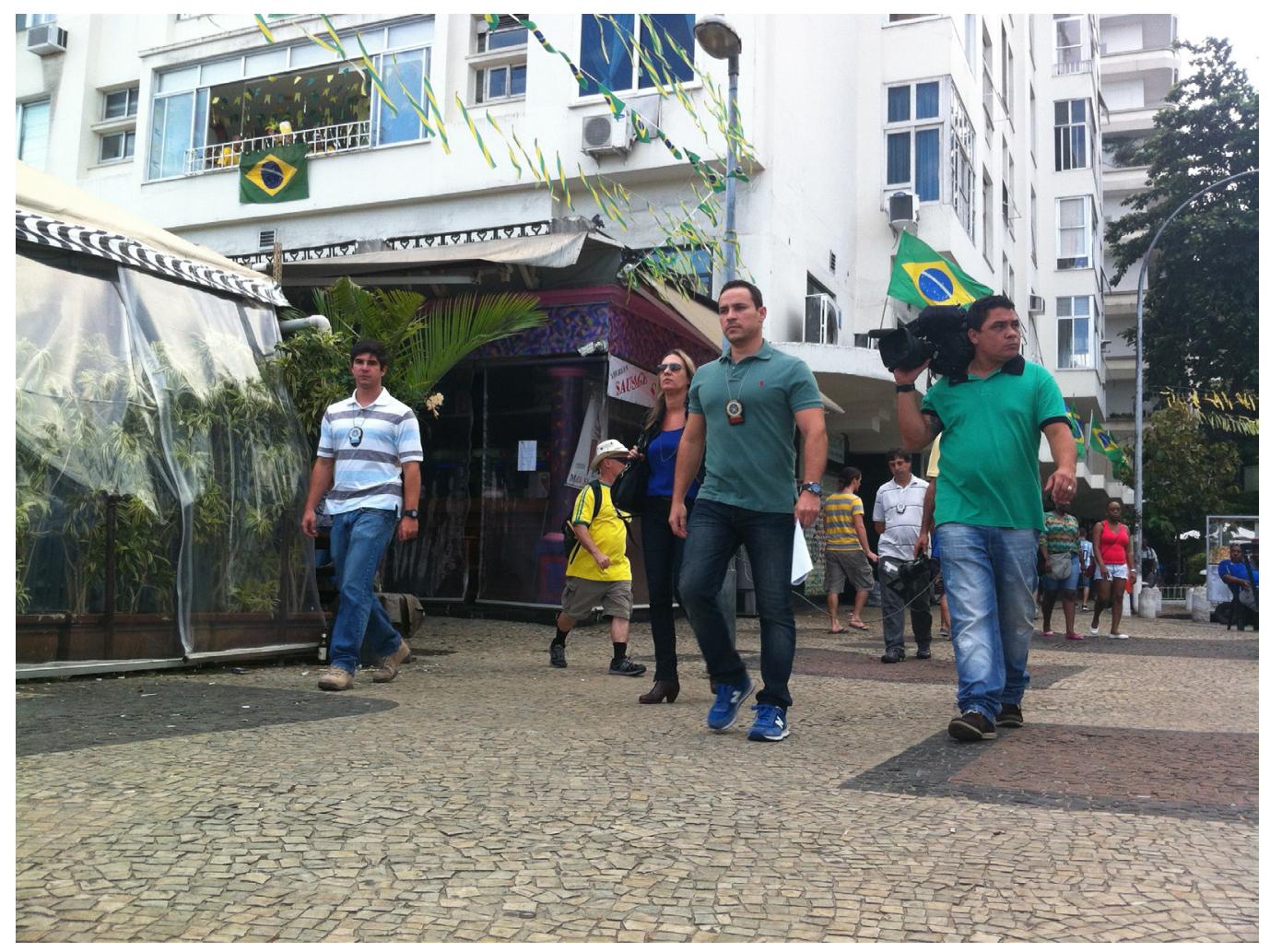

Figura 1. Polícia com 0 Globo invadindo o Balcony. Crédito da foto: Julie Ruvolo. 


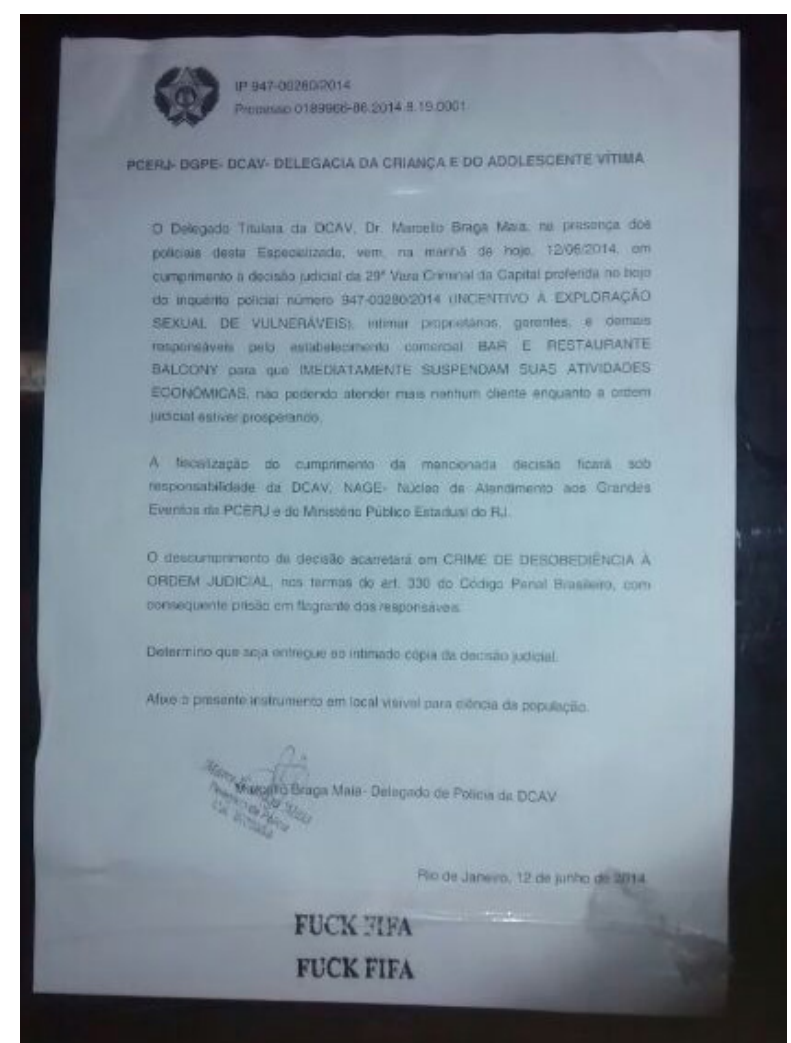

Figura 2. Polícia ordena o fechamento do Balcony Bar. Clientes colaram o adesivo FUCK FIFA logo depois. Fonte: Observatório da Prostituição.

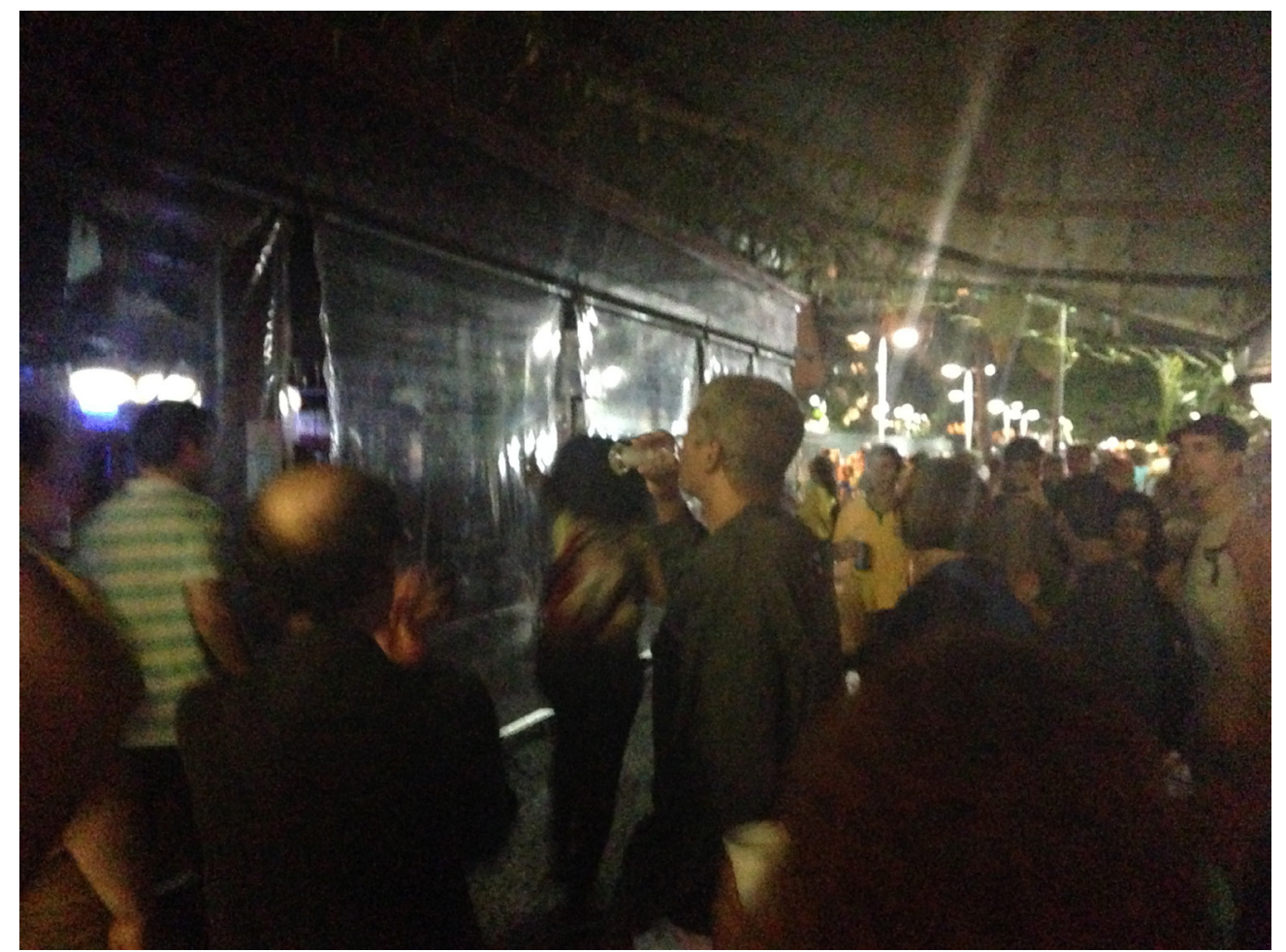

Figura 3. Clientes descobrem que o Balcony Bar está fechado e começam a protestar. Fonte: Observatório da Prostituição. 


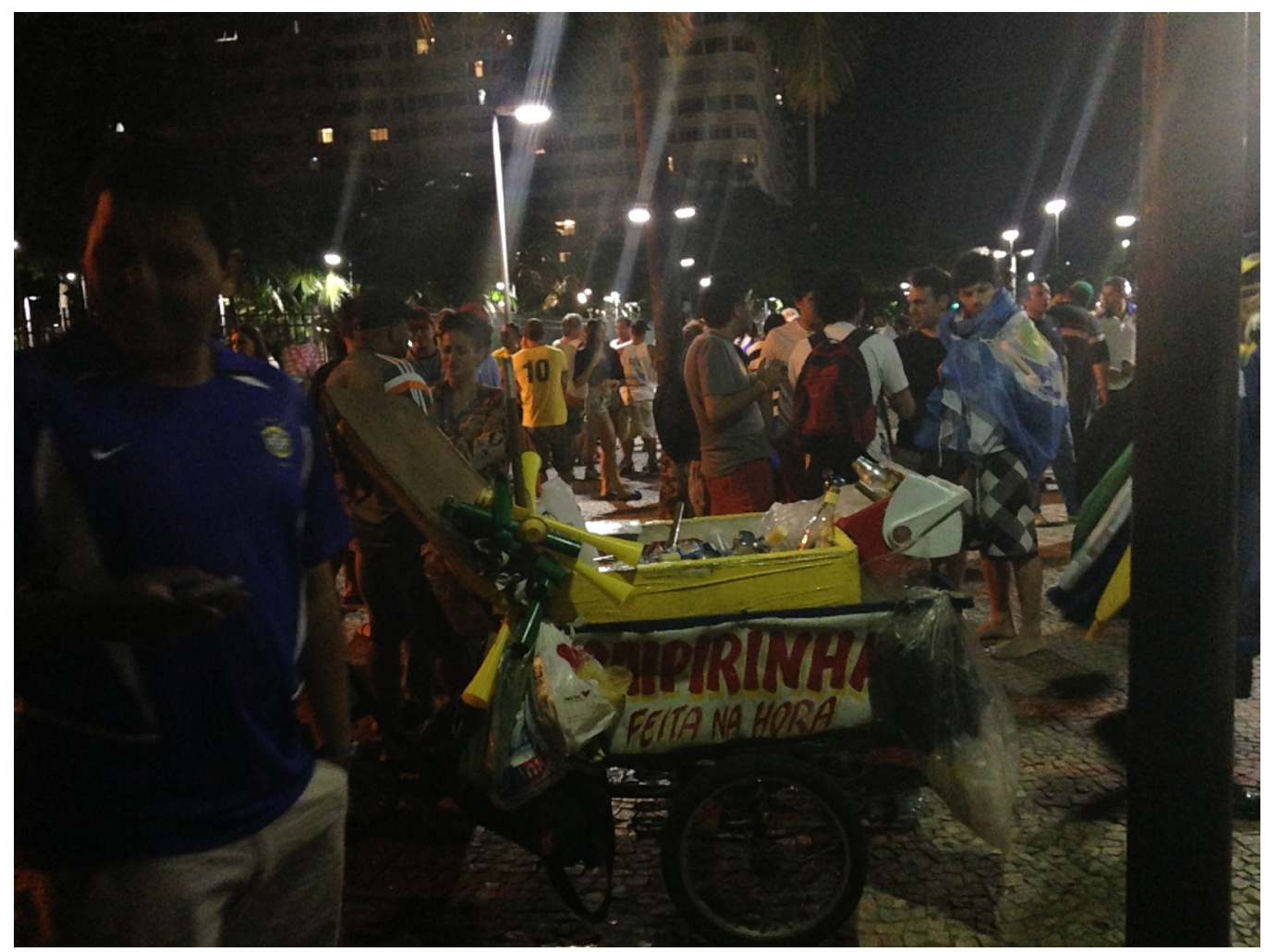

Figura 4. Clientes, vendedores ambulantes e outros fãs da Copa do Mundo rapidamente Iotaram a Praça do Lido, ao lado do Balcony Bar. Fonte: Observatório da Prostituição.

\section{"GRINGO PANIC"}

Na preparação para a Copa do Mundo de 2014, houve muita preocupação com a exploração sexual, especialmente com o "tráfico sexual”. Grande parte dessa preocupação veio de fora do Brasil, graças aos religiosos, feministas e organizações governamentais dos Estados Unidos e da Europa, que estavam excessivamente ansiosos com o evento. Essa retórica foi avidamente adotada pelas autoridades e ativistas brasileiros. A definição de "exploração sexual” ou de "tráfico sexual” nunca ficou clara, pois existem várias e conflitantes definições governamentais. Facilitar a locomoção de uma prostituta em um táxi pode ser tráfico. Emprestar dinheiro a um membro de uma família que seja profissional do sexo para ajudar com uma viagem ou deslocamento pode constituir tráfico. Crianças ou idosos que "vivem às custas" de uma prostituta, morando em sua casa ou sendo seus dependentes, podem ser considerados como "traficantes" ou "cafetões" (BLANCHETTE \& silva, 2017.) A definição de tráfico sexual na legislação brasileira é bastante arbitrária. Grupos feministas antiprostituição tais como a Coalizão Contra o Tráfico de Mulheres (CATW) e Femen (incluindo a sua filial brasileira), assim como organizações cristãs, como o Exodus Cry e o Exército da Salvação, insistem que não se pode consentir com 
a venda do sexo (FArley, 2004; JefFries, 2007; Mickelwait, 2015). Desse ponto de vista, todo tipo de prostituição é exploração e todo tipo de prostituição é forçado ou coagido. Assim, essas organizações frequentemente tomam todas as profissionais do sexo como "vítimas do tráfico" quando citam estatísticas ou quando participam de entrevistas na mídia. Elas comumente confundem pessoas "em risco" de exploração (por exemplo, adolescentes que saíram de casa) com pessoas "exploradas" (Mickelwait, 2015; Weitzer, 2011; VANCE, 2011). Isso leva à inflação estatística do tráfico sexual. Por exemplo, a Aliança Global Contra o Tráfico de Mulheres (Global Alliance Against Traffic in Women - GAATW) - uma organização feminista que claramente faz distinção entre o trabalho sexual consensual e o tráfico - observa que grupos antiprostituição alegam que de 150.000 a 200.000 meninas e mulheres seriam traficadas do México para o Texas para o evento esportivo Super Bowl. Se isto fosse verdade, seria o suficiente para que cada homem, mulher e criança no estádio tivessem sua própria prostituta mexicana (GAATw, 2011, p.23). Apesar desses números frequentemente serem refutados como ridículos, o medo que eles provocam é real. Por causa desse pânico, o dinheiro jorra vindo dos governos, dos paroquianos das igrejas, das celebridades de Hollywood e de outros doadores. No Brasil, grupos evangélicos internacionais, tais como o Exodus Cry, revelaram-se uma força poderosa e lucrativa. O Exodus Cry proclamou:

Enquanto o mundo do desporto começa a atentar-se para o Brasil por causa da Copa do Mundo de 2014 e dos Jogos Olímpicos do Rio de Janeiro, uma equipe do Exodus Cry se prepara para carregar uma tocha de luz, vida e liberdade para essa nação repleta de tráfico humano e de exploração sexual. No Exodus Cry, acreditamos que a oração é a fundação de cada movimento de Deus em favor dos mais vulneráveis... Com belas praias e uma crescente indústria do sexo, estima-se que cerca de 250.000 crianças, geralmente abaixo dos 14 anos de idade, são presas do apetite de turistas sexuais pedófilos vindos dos EUA e da Europa (Exodus Cri, 2013).

O Vaticano anunciou que haveria uma campanha contra o tráfico sexual e a Copa do Mundo chamada "Jogo da Vida" (Official Vatican Network, 2013). Esta campanha envolveu um esforço coordenado com outros grupos, incluindo o governo brasileiro, que começou a publicar anúncios em ônibus e nos aviões que chegavam ao Brasil. Com o título de "Não desvie o olhar", alertava para as pessoas ficarem atentas à exploração sexual de crianças e para denunciarem os casos à polícia. Os anúncios foram exibidos em vinte cidades que participaram da Copa 
do Mundo do Brasil e estrelaram os astros do futebol brasileiro Kaká e Juninho Pernambucano.

Embora organizações religiosas estrangeiras e organizações feministas tenham contribuído para o pânico, um pouco da promoção deste medo veio do próprio Brasil. Por exemplo, a novela Salve Jorge (2012-2013), exibida imediatamente antes da Copa do Mundo de 2014, contou a história de uma mulher brasileira de 18 anos, mãe solteira e batalhadora do Complexo do Alemão (uma localidade composta por 15 favelas na Zona Norte do Rio de Janeiro), que aceita uma oferta de trabalho numa casa noturna em Istambul e acaba sendo traficada e vendida para um grupo de homens por 3.500 dólares. A novela se utilizou dos elementos mais espalhafatosos do melodrama e de uma boa dose de estereótipos racistas sobre turcos morenos e sexualmente ameaçadores, dizendo para as brasileiras terem cuidado com os estrangeiros e suas promessas.

Anteriormente ao Balcony, o maior bar da orla para o turismo sexual era a discoteca Help!, a qual o governo fechou em 2009 e depois demorou anos para demolir e construir o Museu da Imagem e do Som. A notícia foi manchete do jornal britânico The Guardian, que dizia: "Fechamento da casa noturna no Rio deixa prostitutas desamparadas (Helpless): Local notório cederá lugar a um museu na limpeza da cidade antes da Copa do Mundo, preocupando cerca de 2.000 prostitutas" (Phillips, 2009). Este foi um dos maiores exemplos de grilagem de terras que buscou transformar a parte mais visível da economia sexual do Rio em uma maravilha brilhante e moderna da pátria. No momento em que escrevo este artigo, em 2016 - dois anos após a Copa do Mundo - o Museu da Imagem e do Som se encontra com as obras atrasadas, acima do orçamento e ainda não está aberto ao público.

Pouco antes da Copa do Mundo, O Globo publicou uma reportagem especial sobre a vinda dos gringos e a exploração sexual, afirmando:

Daqui a menos de 50 dias começa a Copa do Mundo, e 600 mil estrangeiros deverão desembarcar no país e se somar aos três milhões de brasileiros que, segundo o Ministério do Turismo, se deslocarão entre as 12 cidades-sede durante o evento. O campeonato vai aquecer a economia e mudar a rotina do país, mas também deve deixar crianças e adolescentes brasileiros ainda mais vulneráveis à exploração sexual. Em diversas cidades do Brasil, já há sinais da ação de aliciadores de menores - pessoas dispostas a montar pequenos exércitos capazes de saciar a demanda por sexo (BENEVIDES ET AL., 2014). 
Mais prejudicial do que o discurso, no entanto, foram as incursões policiais. Em 2012, a polícia brasileira invadiu doze estabelecimentos, que funcionavam legalmente, com a alegação de que aqueles locais seriam responsáveis por "encorajar a prostituição". No Brasil, a prostituição é lícita, mas praticamente tudo o que a rodeia não é. Bordéis operam em uma zona lícita, porém cinzenta, onde as profissionais do sexo e os cafetões invariavelmente pagam a polícia para que a discrição seja mantida. Muitos destes locais não estão escondidos e funcionam em plena vista, fazendo propagandas chamativas com placas, panfletos, camisetas e outros apetrechos. Contudo, a polícia visitou o Centaurus, na elegante Ipanema, uma das mais caras e exclusivas termas da cidade e um ponto de encontro para políticos de alto escalão e de celebridades como Justin Bieber, que foi fotografado enquanto deixava o Centaurus em 2013. Aproximadamente 100 agentes trabalharam para fechar temporariamente o Centaurus e invadiram onze locais parecidos, incluindo o L'uomo, Café Sensoo, La Cicciolina, Barbarella, Don Juan, Nightclub Calabria e outros destinos populares entre turistas sexuais e moradores. O mandado justificava as incursões com a seguinte sentença:

[...] não podemos esquecer que há uma certa tolerância e indiferença em relação aos bordéis, mas, na maior parte dos casos, estes estabelecimentos são usados não apenas com o propósito de exploração sexual e encontros sexuais, mas também para a exploração sexual de adolescentes, lavagem de dinheiro de grupos mafiosos, tráfico de drogas, porte de arma de fogo, corrupção policial, entre outros" (Borges, 2012).

Embora tenha havido uma grande pressão naquela época, todos os locais reabriram e continuaram com seus negócios como de costume. A polícia os deixou em paz e nada mais aconteceu. A opinião geral, mas sem fundamento, dos funcionários e das profissionais do sexo é que a polícia decidiu que era mais lucrativo voltar para o antigo sistema de pagamento e de policiamento.

Em sua propagação de pânico moral sobre os gringos predadores sexuais, o governo brasileiro alegou que houve um crescimento de 30\% nos casos de exploração de crianças e adolescentes na África do Sul durante a Copa do Mundo de 2010 (VERDELIO, 2014). Enquanto alguns grupos haviam previsto tal aumento na África do Sul, na verdade, aquele país não teve casos confirmados de tráfico de adultos ou crianças relacionados à Copa do Mundo. Em artigo intitulado "A crise da Copa que nunca existiu", a jornalista sul-africana Kashiefa Ajam relatou: "40.0oo: são os casos de tráfico humano previstos na Copa do Mundo. Zero: é o número de 
casos reais que foram reportados" (AJAM, 2013). Apesar de não haver nenhuma evidência real de um problema, ainda assim, estimulado pelo Vaticano e pelos cristãos evangélicos, o governo brasileiro investiu em campanhas de conscientização antitráfico e financiou o lançamento da campanha em 19 países da África e da Europa, a fim de educar os gringos de todos os lugares.

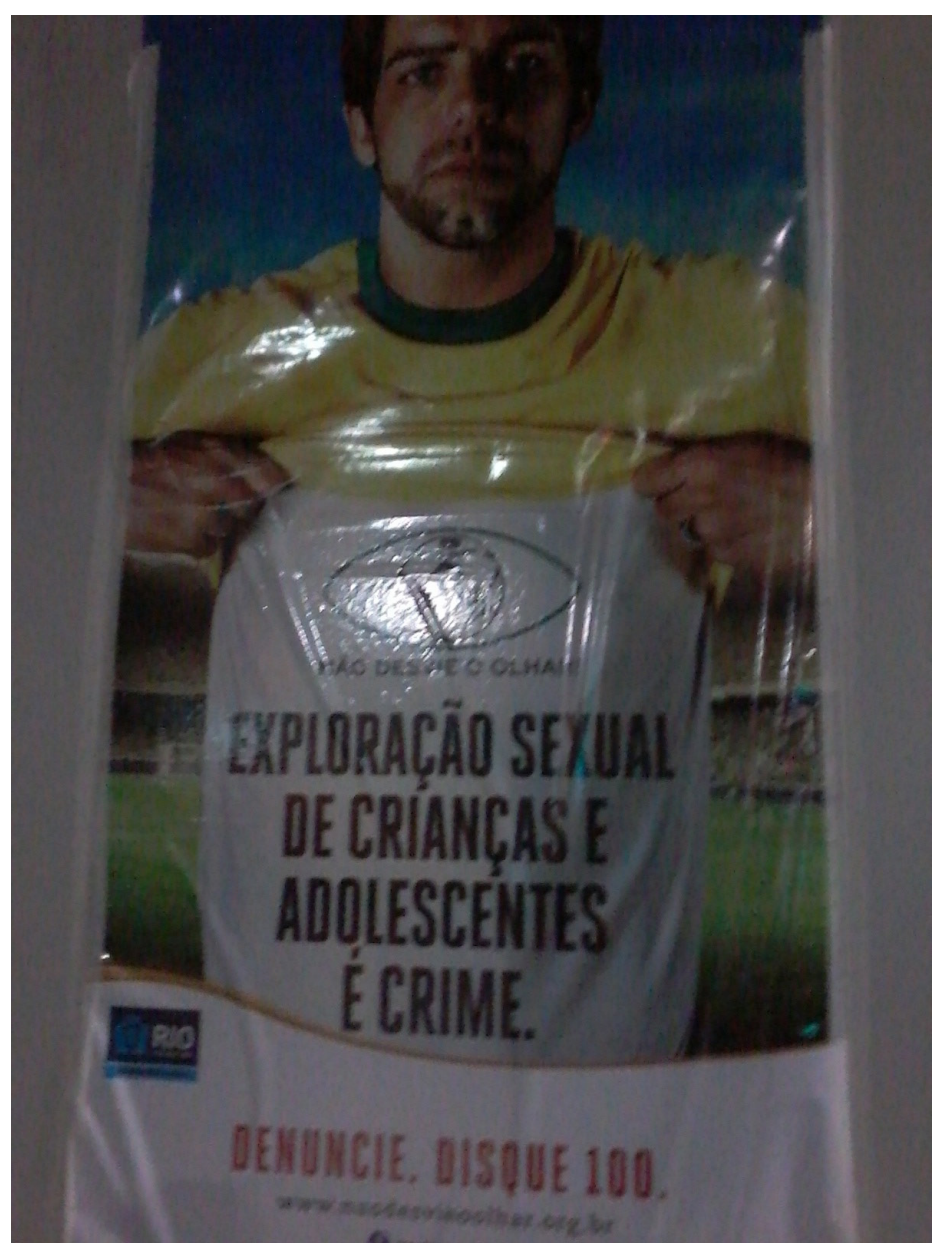

Figura 5. Um cartaz pendurado ao lado do Balcony Bar aconselhando o público a denunciar a exploração sexual de crianças. Fonte: Observatório da Prostituição.

\section{MÉTODOS}

Em 2014, eu participei da fundação do Observatório da Prostituição, no Instituto de Filosofia e Ciências Sociais da Universidade Federal do Rio de Janeiro (UFRJ/IFCS). A equipe do Observatório que trabalhou na Copa do Mundo era composta por estudiosos do Brasil, Portugal, Canadá e Estados Unidos, assim como por colaboradores da Associação Brasileira Interdisciplinar de AIDS (ABIA), um jornalista e documentarista independente e o Davida, uma organização que promove a cidadania e os direitos das profissionais do sexo. Embora os membros 
da equipe fossem etnicamente diversificados e com idades variando entre o início dos vinte ao final dos quarenta anos, nós geralmente nos assemelhávamos às pessoas que frequentavam esses lugares. Na verdade, as pesquisadoras frequentemente eram confundidas com profissionais do sexo e os pesquisadores com clientes. Por ser um gringo branco em torno dos trinta anos (com sotaque estadunidense), as profissionais do sexo quase sempre esperavam que eu fosse um potencial cliente até o momento em que eu explicava o projeto de pesquisa. Os clientes também frequentemente me tratavam de maneira conspiratória como se eu fosse um turista sexual parceiro (por exemplo, fazendo gestos ou comentários sexuais sobre as mulheres). Os quatro pesquisadores do sexo masculino tiveram acesso à área interna do bordel que fora negado às pesquisadoras; sendo assim, nós frequentemente dividíamos nossos territórios geograficamente. Do mesmo modo, alguns pesquisadores se identificavam com diferentes lugares e, por isso, às vezes nos despachávamos segundo essa conformidade. Focamos-nos no Rio de Janeiro, pois essa é a cidade brasileira mais frequentada por turistas e porque nós recrutamos membros da Associação Brasileira Interdisciplinar de AIDS (ABIA), da Universidade da Cidadania/UFRJ e da Rede Brasileira de Prostitutas. Assim, o Rio de Janeiro apresentava características próprias, nem sempre presentes em outras cidades hospedeiras. No entanto, nós compartilhamos informações com pesquisadores independentes que trabalharam durante a Copa nas cidades de Fortaleza e Campinas. O trabalho etnográfico (incluindo a observação dos participantes e entrevistas formais e informais) foi o nosso método principal, embora a equipe também tenha feito uma breve pesquisa qualitativa sociológica que informava nosso trabalho ${ }^{4}$.

4 Em 2012, dois membros do Observatório concluíram um mapeamento extensivo dos vários pontos de prostituição no Rio de Janeiro, fruto de 8 anos de investigações etnográficas e sociológicas. Esse mapeamento nos permitiu identificar os principais pontos de prostituição frequentados por brasileiros e estrangeiros na cidade. Nesse mesmo ano, outras e outros pesquisadores que colaboram com o Observatório estiveram nesses pontos, em vários momentos do ciclo sazonal da atividade, que tem muitas variações ao longo do ano. Em 2013, essa ronda periódica de visitas foi intensificada, concentrando-se nos 20 pontos de comércio sexual mais frequentados por turistas estrangeiros, na Vila Mimosa, e nos 20 pontos mais movimentados da área central da cidade do Rio de Janeiro. Entre novembro de 2013 e maio de 2014, visitamos esses lugares pelo menos uma vez por mês, geralmente nas primeiras semanas do mês (quase sempre após o pagamento dos salários), para conseguir uma contagem média de número e tipo de trabalhadoras e clientes ativos nesses locais. Durante esse período, fizemos entrevistas com as prostitutas, gerentes, seguranças e outros trabalhadores desses pontos sobre seus planos e perspectivas para a Copa do Mundo. No total, estimamos que, durante a Copa do Mundo, a equipe realizou mais de 2.00o horas de pesquisa etnográfica baseada em observação participante, nas áreas onde o sexo é comercializado no Rio de Janeiro. Nos últimos dias do evento e nas semanas imediatamente posteriores, fizemos 116 entrevistas formais (com questionário) com trabalhadoras sexuais que estiveram ativas durante o evento, perguntando sobre suas expectativas e experiências. Com todas as mulheres entrevistadas, compartilhamos informações sobre nossos objetivos como grupo de pesquisa e esclarecemos seus direitos como participantes da investigação. Em parceria com 
Embora tivéssemos interesses próprios e projetos de pesquisa separados, concordamos em compartilhar os dados e coordenar nossos esforços, porque sabíamos que precisaríamos de pesquisadores presentes em diversos lugares, antes, durante e após os 32 dias da Copa do Mundo, caso quiséssemos compreender a verdade sobre a prostituição e a Copa. Esta variedade de locais incluiu dezenas de lugares em Copacabana, outras dezenas de locais de classe média e baixa no Centro, assim como na Vila Mimosa, uma área pobre não muito longe do Maracanã onde até 1.000 mulheres trabalham. Isso significa que havia pesquisadores em espaços internos e externos que serviam a diversas classes sociais, monitorando o comércio, contando o número de prostitutas e clientes, determinando a nacionalidade das profissionais do sexo e dos clientes e conversando com as prostitutas, funcionários e clientes. Em particular, para verificar se a migração estava acontecendo, nós precisávamos conhecer a história profissional das mulheres, se elas vinham de outras áreas do Brasil ou do exterior, se elas geralmente trabalhavam no comércio sexual ou se estavam vendendo sexo especialmente por causa da Copa. Outros pesquisadores e eu elaboramos esses achados em diferentes publicações (Blanchette; Mitchell; Murray, 2015; Mitchell, 2016a, Mitchell, 2016b).

O mais importante para os fins deste artigo é que encontramos evidências irrefutáveis de que a prostituição não cresceu significativamente durante a Copa no Rio. As profissionais do sexo, muitas das quais pensaram que ficariam ricas, ficaram muito desapontadas. Diversos locais permaneceram fechados nos dias dos jogos, pois os negócios estavam muito ruins. A movimentação na Vila Mimosa caiu 30-50\% apesar do fato de que se encontrava próxima ao estádio. Os negócios aumentaram em Copacabana, mas isso foi apenas uma recentralização do trabalho, pois as mulheres abandonaram a Vila Mimosa e o Centro para caçar gringos na Zona Sul. Apesar das centenas de horas de trabalho de campo nas dezenas de maiores e menores locais de comércio sexual e por meio de uma variedade de

Davida, produzimos e distribuímos uma versão pocket do jornal “O Beijo da Rua”: o "Beijinho da rua" com informações sobre direitos e saúde para prostitutas e seus clientes, em português e em inglês. Reuniões de trabalho semanais aconteceram ao longo dos meses de maio, junho e julho, para coordenar as equipes, compartilhar dados e percepções, ajustar os parâmetros da pesquisa e definir estratégias de diálogo com agentes públicos e a mídia. A Associação Brasileira Interdisciplinar de Aids (ABIA), parceira da pesquisa, gentilmente cedeu sua sede institucional para funcionar como "quartel-general" da pesquisa. Este artigo apresenta os achados e insights preliminares que resultaram desse esforço de investigação. A Copa do Mundo foi considerada "ruim" pela maioria das trabalhadoras do sexo que ouvimos no Rio de Janeiro. Apesar da presença de um número significativo de turistas (nacionais e estrangeiros) na cidade, houve um declínio no comércio sexual durante os 32 dias do evento. Dos 83 pontos de prostituição pesquisados, apenas 17 locais registraram aumento de atividade e em 6 outros pontos o fluxo de clientes foi normal. Em contraste, nos demais 6o pontos - inclusive na Vila Mimosa (onde trabalham cerca de 1.000 mulheres) - a queda estimada no movimento de clientes variou de $30 \%$ a $50 \%$, entre 12 de junho e 13 julho. 
tipos e classes de lugares, nenhum dos nossos pesquisadores pode documentar um único caso que causasse alerta para um possível caso de tráfico sexual. De fato, nem o Governo pôde fazer isso, o que não surpreende, pois os representantes governamentais não estavam presentes nesses lugares. Assim como no caso da África do Sul, defensores da antiprostituição persistiam em confundir o trabalho sexual com o tráfico após a Copa, produzindo estatísticas imprecisas e assumindo que qualquer caso de prostituição forçada ou de alcoviteiros (o que não é tráfico) coincidindo com a Copa, era por causa da Copa (veja, por exemplo, VerdAdE GosPel, 2014). Apesar de fazer alegações sobre a exploração, eles não podiam produzir casos reais.

Em suma, criou-se um tremendo pânico acerca da exploração sexual antes da Copa. Isso permitiu aos cristãos evangélicos, aos ativistas antiprostituição e à polícia realizarem expedições de incursão e limpeza social nas "zonas de luz vermelha”, o que auxiliou na gentrificação desses locais. Como descrevo em outro artigo, essas incursões forçaram as mulheres a trabalharem em outros lugares, incluindo áreas perigosas a céu aberto e, além disso, algumas incursões chamaram a atenção dos grupos de direitos humanos internacionais, pois houve espancamento, roubo e estupro coletivo das mulheres provocados por policiais (ver Mitchell, 2016b). Isso aconteceu às custas das profissionais do sexo e, na verdade, encorajou o desenvolvimento da prostituição de menores e da exploração sexual que, com todo esse esforço, estavam supostamente tentando combater. O que se segue é uma análise de como ideias mal concebidas sobre os gringos contribuíram para o desenvolvimento desta situação. O meu argumento é que a Copa do Mundo não atraiu gringos predatórios, como se imaginava em meio ao pânico, mas na verdade trouxe, inusitadamente, gringos ingênuos que foram vistos pelas prostitutas como presas fáceis. No entanto, as "reformas" em Copacabana, justificadas durante essa época do "pânico", criaram as condições para que o comércio sexual no Rio de Janeiro se tornasse mais - e não menos - vulnerável e marginalizado. Destaco ainda que os verdadeiros perigos para estas mulheres não vieram dos gringos, mas da polícia.

\section{GRINGOS BONS}

Enquanto permanecia na Praça do Lido, diretamente ao lado do Balcony Bar, que fora interditado, entre centenas de profissionais do sexo e clientes, percebi dois iranianos que aparentavam ter 40 anos. Os dois homens pareciam a versão persa de O Gordo e o Magro (Laurel e Hardy, na versão original): um era baixo, gordo e efusivo e o outro era alto, magro e tímido. Foi fácil deduzir que eram iranianos, pois 
usavam roupas combinando, incluindo camisas estampadas com a palavra "IR Ã". Sob suas camisas do Irã, eles usavam camisetas de alças brancas que eram visíveis por causa do seu contorno com nervuras e também usavam meias 3/4 pretas com bandeiras iranianas. Poucos centímetros dos joelhos peludos eram visíveis entre as meias e seus shorts cáqui, que estava escondido por suas enormes pochetes repletas de dinheiro, mapas, guias e eletrônicos. Os dois usavam relógios quase idênticos, os quais também eram enormes e pareciam ser muito caros para serem usados na noite de Copacabana. Parecia impossível para mim que esses gringos estivessem em posse de todos os seus pertences na manhã seguinte.

O Gordo e o Magro tentaram negociar com uma prostituta brasileira. Ela era branca com cabelos negros, talvez tivesse 30 anos, usava um vestido curto que quase não cobria sua bunda. O Gordo conversava, perguntando o valor do programa. Ela queria 300 reais, mas ele ofereceu 200. Ele fazia um grande esforço para falar inglês e eles tinham certa dificuldade em compreender os sotaques. Ele sacou seu iPhone e o utilizou para escrever o número 200. Ele apontou para o número enfaticamente. Depois disse:

- Para nós dois.

- Os dois juntos? Perguntou. - Juntos? Ela parecia confusa com esta demanda. - Não! Ele disse, parecendo enojado. - Primeiro eu. Depois ele.

O gordo sorriu satisfeito com seu plano. Ela olhou para O Gordo e depois para O Magro. O Magro olhou timidamente, baixando o olhar e dando de ombros.

A mulher olhou, novamente, para O Gordo, revirou os olhos e depois foi embora. Ela se aproximou de outro gringo. Este era mais novo, em torno dos 30 anos, musculoso e bonito. Mas este fortão não tinha muito dinheiro. Os valores das mulheres eram mais altos do que ele esperava, então ele queria apenas um boquete, esperando que isto fosse barato. Ela lançou-lhe um olhar de desprezo, chocada com a possibilidade de perder tempo de trabalho fazendo um boquete barato. Eles começaram a se afastar juntos; contudo, ela parecia inclinada o suficiente a concordar com o que seria ao menos um pouco de dinheiro rápido. $\mathrm{O}$ Gordo e O Magro assistiram ela sair com o fortão. Eles ficaram lá por um momento, uma pequena área de espaço vazio os circundava. Lá estavam eles, sozinhos e incapazes de ficar com alguém mesmo numa multidão de prostitutas. O Gordo bufou, recusando-se a olhar para O Magro e parecia aborrecido o suficiente para conversar com outra mulher. 
Duas mulheres jovens e brancas, aparentando ter 20 anos, se aproximaram deles. Elas tinham cabelos loiros escuros no estilo das garotas da Zona Sul (e das mulheres que querem se parecer com as garotas da Zona Sul). Elas pareciam ser amigas e se conhecer bem. Para mim estava claro que uma delas era uma travesti, pois eu interajo com travestis e mulheres transgênero quase todos os dias. Acho que ela "passaria" facilmente para muitas pessoas não familiarizadas com as nuances da performatividade de gênero entre as travestis brasileiras (que é uma subjetividade de gênero diferente das mulheres transgênero) e eu acho que os iranianos não haviam percebido. Eles mal olharam para as mulheres e O Gordo começou com a barganha, digitando números na calculadora do celular.

A mulher cisgênero manteve $O$ Magro ocupado enquanto a travesti censurava O Gordo por suas tentativas irreais de negociação. As mulheres trocavam olhares e sussurravam em português entre si criticando aqueles gringos pão duros, enquanto a travesti lutava para comunicar seu descontentamento em inglês para O Gordo.

- Where you stay? (Onde você ficar?) - Ela perguntou, sem ao menos se preocupar em paquerar ou seduzir.

O Gordo se animou. Ele entendeu algo!

- Barra! We stay Barra da Tijuca! Very nice Hotel! (Barra! Nós ficar Barra da Tijuca! Hotel muito legal!) - O Gordo preconizou.

Olhares mais significativos entre as prostitutas. Um aceno com a cabeça da mulher cisgênero. A travesti concordou com o preço digitado no telefone: 200 reais.

- 20o for her. 200 for me (200 pra ela. 200 pra mim) - ela explicou.

- 200 total! (200 total!) - Disse O Gordo.

- No! (Não) - A travesti disse vagarosamente, pacientemente, como se estivesse conversando com uma criança. - 20o for her. 200 for me. One hour. (200 pra ela. 200 pra mim. Uma hora).

- OK! - Concordou O Gordo.

- We take taxi now to Barra. We go to hotel with you (Nós pegamos táxi agora pra Barra. Nós vamos para hotel com vocês) - ela explicou, arrastando-o para o meio-fio para chamar um táxi. Seu enorme relógio refletia sob as luzes da rua. - First you pay. You pay us now. (Primeiro você paga. Você nos paga agora).

O Magro caminhou nervosamente logo atrás d'O Gordo, que parecia estar muito excitado com a sacanagem que estava prestes a acontecer, agora que a discussão financeira havia terminado. Eu me perguntava o que aconteceria quando 
eles chegassem no bairro rico, em seu hotel chique e tentassem levar as mulheres para os seus quartos. Imaginei os recepcionistas tentando explicar para O Gordo que sua amiga travesti não poderia acompanhá-lo e que eles teriam que encontrar um motel para consumar tal objetivo. As mulheres, é claro, já sabiam. Mas até lá elas já teriam recebido seu dinheiro ou pediriam mais dinheiro. O Gordo não perguntou quando sua hora começaria. A Barra ficava longe, a cerca de quarenta minutos. É claro que se eles chegassem ao hotel e eles não quisessem pagar, as mulheres poderiam fazer um escândalo. O antropólogo Don Kulick (1996) entrevistou extensivamente prostitutas travestis sobre suas táticas para extrair dinheiro adicional dos seus clientes fazendo um escândalo em público para chamar a atenção para a relação sexual dos homens com elas. Eu daria tudo para estar no saguão para assistir a essa performance.

Ou talvez os iranianos conseguissem passar com as mulheres pela recepção e levá-las aos seus quartos. Pergunto-me o que aconteceria quando eles percebessem que uma das mulheres era uma travesti. Ficaria o Gordo surpreso? Nervoso? Excitado? Ou talvez ele fosse mais experiente do que eu imaginara e já soubesse de tudo. Fico imaginando se os homens seriam tão descuidados com seus objetos de valor no quarto do hotel como foram com seus objetos de valor que carregavam pelas ruas. E imagino quantos outros jeitinhos as mulheres reservavam para aquela noite. Escrevi um lembrete para procurar pelas mulheres na noite seguinte e perguntar-lhes como foi, mas nunca mais as vi novamente. Espero que elas tenham abandonado a cena do comércio sexual porque a noite teve um final muito feliz e não devido a um final ruim, mas nunca descobri o que houve. Essa é a natureza da etnografia.

O Gordo e O Magro eram turistas típicos que compravam sexo de várias maneiras durante a Copa do Mundo. Tal como a descrição etnográfica acima retirada das minhas notas de campo - ilustra, eles não tinham experiência com a economia sexual. Na verdade, eram muito ingênuos. Eles não conheciam os preços apropriados, careciam de qualquer facilidade linguística com o português e tinham dificuldades em compreender as mulheres quando elas tentavam falar em inglês. Eles não compreendiam como a mecânica de um programa funcionava ou quais detalhes eles deveriam ter negociado: Quanto tempo dura? Onde os programas são realizados? Quais ações estão incluídas? Preservativos serão utilizados e, caso positivo, quem deveria fornecê-los? Quando deveriam pagar? Quanto deveriam pagar, baseados nesses fatores? Na verdade, os iranianos eram pobres turistas sexuais que eram tímidos para se aproximar e negociar com várias mulheres. Eles, finalmente, conseguiram uma prostituta para cada, mas apenas porque as mulheres 
estavam trabalhando juntas. Eles quase praticaram sexo a três, mas pareceu que isso teria acontecido por causa do constrangimento causado pela negociação e não porque eles de fato queriam compartilhar uma mulher ou ter um vínculo homossocial ou homoerótico. Eles só conseguiram uma prostituta para cada um porque as mulheres estavam trabalhando juntas e decidiram formar uma dupla.

Na verdade, os membros do Observatório e eu vimos esse padrão se repetir. Turistas sexuais na Copa do Mundo não vieram especificamente para comprar programas. Muitos deles vieram para observar o ambiente excitante, mas não queriam pagar. As mulheres reclamavam que os gringos queriam conversar, talvez pagar-lhes uma bebida e que todos queriam tirar selfies para postar no Facebook, mas eles não queriam pagar. Eram gringos maus. Eles desperdiçavam o tempo das mulheres e as afastavam de clientes que estavam dispostos a pagar. Sem sombra de dúvida, os gringos durante a Copa do Mundo pagaram preços superfaturados pelos programas. Turistas sexuais que frequentemente vêm para o Brasil sabem o quanto custa o programa em um determinado local e com uma determinada mulher. Já os gringos desavisados que vieram para a Copa foram facilmente explorados.

Assim como os iranianos, vi muitos casos de gringos ficando confusos e perguntando se eles poderiam compartilhar uma mulher. Na verdade, imediatamente após os iranianos saírem, eu escutei dois homens italianos, que tinham por volta de vinte e poucos anos, se aproximarem de uma jovem mulher morena, que estava no final da adolescência ou no início dos vinte anos, e pedirem-na para fazer sexo com os dois. Deste modo eles esperavam por um desconto. Eles falaram em italiano, mas ela respondeu em português, dizendo que estava muito cansada para fazer tal programa. Era mais provável que essa recusa era sua maneira de evitar uma situação potencialmente perigosa. Os homens continuaram pedindo e ela se ofereceu para encontrar uma segunda mulher, mas eles realmente queriam o sexo a três com um desconto. Assim como aconteceu com os iranianos, a primeira mulher foi embora e uma dupla de mulheres que estavam trabalhando juntas apareceu imediatamente e socializaram com eles, de modo que cada um pudesse ter uma mulher. Mas, novamente, eles não queriam pagar o dobro.

Os italianos pensavam que eram negociadores astutos. Eles fingiam que iam embora, mas retornavam para negociar novamente. Depois eles repetiam essa tática de ir embora, mas ficavam olhando pelos ombros para ver se as mulheres iriam se arrepender e chamá-los de volta em vez de perder o programa. Não foi um ato muito convincente. As mulheres apenas os deixavam ir embora. Certamente, qualquer um com experiência saberia que nenhuma prostituta daria um desconto de 50\% no primeiro programa da noite e certamente não na noite de abertura da 
Copa, quando elas ainda esperam fazer uma pequena fortuna. No final de uma noite não muito movimentada, as prostitutas com certeza poderiam fazer isso e algumas ainda iriam fazer programas gratuitos pela oportunidade de pernoitar com algum cliente e evitar uma longa viagem ou uma corrida de taxi cara na volta para a Zona Norte, onde muitas residem (taxistas sabem disso e frequentemente aparecem no final da noite oferecendo corridas gratuitas em troca de sexo). Os italianos finalmente pararam de andar e, olhando tristemente para as mulheres que eles desejavam, pegaram suas carteiras. Eles se aproximaram, sussurrando, e começaram a contar o dinheiro para ver se tinham reais suficientes para atingir o preço das mulheres. A última vez que os vi, eles estavam caminhando vagarosamente de volta para as mulheres com suas carteiras vazias oferecendo todo o dinheiro que tinham por um programa. As mulheres sorriram. Estes eram gringos bons.

De acordo com o antropólogo Thaddeus Gregory Blanchette (2012), as mulheres possuem várias nomenclaturas para descrever os gringos. Seus conhecimentos sobre os gringos são diferentes da imagem do gringo utilizada pelo governo e até mesmo pela mídia. Elas falam sobre gringos bons. De acordo com Blanchette (2012, p.75), "para as prostitutas de Copacabana, 'gringo bom' é aquele recém-chegado, que fala pouco ou nenhum português e paga os programas sem pechinchar". Assim as mulheres coletivamente me explicaram na pesquisa de campo: gringos bons pagam bem, muito mais do que os brasileiros. Um gringo bom usa preservativo, é educado, não tenta fazer sexo anal ou outras atividades que não foram negociadas anteriormente, e goza rápido. Gringos bons podem se tornar clientes regulares e frequentemente ficam por períodos longos para que a mulher possa fazer vários programas com ele durante sua estadia. Às vezes um gringo bom a pede em namoro ou apresenta oportunidades de imigração. Muitas prostitutas reportaram para Blanchette e da Silva que, caso encontrassem um gringo bom, elas tentariam engravidar de modo a influenciar no processo de imigração ou para receber pensões mensais (Blanchette; Silva, 2005). Esse também é um fenômeno estudado extensivamente pela cientista social brasileira Renata Melo Rosa (1999), cujas pesquisas mostram que o amor e o apego emocional estimulam migrações transnacionais de mulheres brasileiras de formas tão complicadas que confundem as fronteiras de constructos, tais como o "turismo sexual". Por outro lado, essa estratégia de engravidar também pode terminar de forma trágica para as mulheres que carregam os filhos dos gringos, certamente.

As prostitutas também falam depreciativamente dos gringos aos quais elas se referem com a gíria "fariseus", um termo que reflete o histórico evangélico 
cristão de muitas delas. Fariseus são gringos que se sentem moralmente superiores quando estão comprando um programa. Os gringos que desperdiçaram o tempo das mulheres oferecendo bebidas, querendo conversar e tirar selfies para o Facebook, mas não compraram um programa, pois achavam que eles não "precisavam" pagar pelo sexo, eram fariseus. Como uma prostituta explicou para Blanchette no campus do Observatório,

Fariseu é aquele gringo que se acha melhor que a gente. Ele fala português e sabe agir como brasileiro. Nem fode, nem sai de cima: ele gosta de ter a garota em torno de sua mesa, fazendo mis en scène, fazendo-o se sentir o máximo, mas na hora do programa, não quer pagar" (BlancheTte, 2012, p.73).

As mulheres que entrevistei também falaram muitas vezes sobre os "gringos latinos":

- Existem gringos e existem gringos latinos - explicou Priscilla. - Gringos são bons. Eles são bem melhores do que os brasileiros! Mas gringos latinos são horríveis [...] os gringos latinos nunca querem pagar. Ele não tem dinheiro, mas acha que deveria ter sexo de qualquer maneira! Ridículo!

Quando perguntei quem entre os gringos latinos eram os piores, ela rapidamente apontou duas nacionalidades:

- Os chilenos! - Disse ela, revirando os olhos. - Esses carinhas sempre mordendo nossos tornozelos! Eles querem xoxota, xoxota, xoxota, mas eles não têm dinheiro! Oh, e os argentinos, é claro. - As mulheres sempre reclamavam sobre transar com argentinos, mas isso também refletia as rivalidades sociopolíticas e do futebol.

Também havia muitas caravanas desses dois países no Rio de Janeiro.

- Eles vêm aqui e pensam que a xoxota vai custar 20 reais! - Ela riu. - Pega isso e vai no Centro, vai num fast foda (tipo de bordel) onde custa um real por minuto. Por um programa de uma hora? Eu espero que você venha para as ruas de Copacabana e me traga 250, 300. Às vezes eu ganho 400. Certa vez minha amiga ganhou 500 de um gringo. 
Grupos de amigos ficavam com cerca de seis ou sete homens numa van ou carro, dormindo no veículo estacionado. Esses grandes grupos de gringos latinos foram uma irritação para a polícia brasileira e para outros empresários, não apenas para as prostitutas. Em uma entrevista que conduzi com um agente do FBI dos EUA que estava trabalhando com a polícia militar e a polícia civil no Brasil, em relação aos problemas de segurança na Copa do Mundo, ele explicou que a polícia estava sempre lidando com o mau comportamento dos grupos de gringos chilenos que faziam festas nas ruas, ficavam bêbados, arranjavam brigas e geralmente causavam problemas.

Existem turistas sexuais especialistas que participam de fórum de discussões na internet, onde deixam resenhas e informações sobre bordeis e mulheres. Eles referem-se a si mesmo como mongers (traficantes/vendedores), que vem do termo whoremonger (devasso), e debatem sobre os melhores pontos de turismo sexual no Brasil (e às vezes sobre outros países, dependendo se eles são especialistas no Brasil ou se são generalistas e compram sexo em outros países e regiões). Eles se orgulham por nunca pagar mais do que o necessário e por pagarem o mais barato possível. As mulheres não gostam de tais gringos, os acham irritantes ou decepcionantes, mas os respeitam, pois são essencialmente gringos que agem como brasileiros.

Existe uma disjunção entre a imagem que o governo passa sobre os gringos, rotulando-os como predadores, e a percepção das prostitutas sobre os gringos. O governo sempre está preocupado com os gringos turistas sexuais que podem explorar mulheres e crianças, mas enfatizar a natureza predatória dos gringos turistas sexuais durante os grandes eventos baseia-se em estereótipos do fã de futebol hipermasculino, sexualmente agressivo e imoral, associando ideias sexistas sobre homens com premissas de que os fãs de esportes serão mais suscetíveis a prejudicar as mulheres e crianças. Não existe, de fato, nenhuma evidência de que um fã de esporte seria mais suscetível a explorar alguém sexualmente do que um gringo que não gosta de esportes. Na verdade, faria mais sentido que o gringo visitando um evento esportivo estivesse mais interessado no futebol e encontrasse sexo apenas incidentalmente. Não é tão provável ele sair da sua rotina para encontrar algum local oculto, um bordel clandestino, com meninas menores de idade. Ele não tem conhecimento o suficiente para acessar as áreas mais obscuras de uma economia clandestina. Caso compre sexo, é mais provável que ele o obtenha no local mais turístico possível, ou seja, na área próxima ao Balcony, onde seria menos provável haver crianças prostitutas... pelo menos até o governo o interditar. 
Na verdade, muitos gringos fãs de esporte com os quais conversei eram fariseus. Às vezes eles poderiam ser convencidos por uma prostituta agressiva a comprar um programa, mas eles não tinham planejado essa eventualidade. Eles eram o que Blanchette e da Silva (2005) se referiram como "turistas sexuais acidentais". Muitos destes gringos esperavam sair com uma mulher brasileira, mas se essa oportunidade não aparecesse num bar ou nos aplicativos de relacionamento como o Tinder eles iriam se contentar, no fim da sua viagem, com uma prostituta. Também houve alguns gringos que elevaram os níveis da tendência fariseu, direcionando-a para excitantes modos de espectador, como um pequeno grupo de fãs de futebol ingleses que colocou cadeiras dobráveis e um isopor com cervejas na calçada da praça para assistir ao comércio sexual como se aquilo fosse um show. Eles não compraram programas, mas ficavam fazendo comentários e irritando as mulheres.

Estudando a economia sexual do Rio de Janeiro antes, durante e depois da Copa do Mundo, ficou claro que os fãs de esporte que vieram ao Rio durante esse megaevento, sendo fariseus ou gringos bons, eram neófitos. Longe de serem homens predatórios que explorariam as mulheres, os turistas sexuais durante a Copa do Mundo eram apreciados pelas mulheres como os alvos mais fáceis que encontraram ao longo dos anos. Outra mulher, Pâmela, explicou, enquanto olhávamos da nossa mesa para a multidão de homens que começavam a aparecer nos arredores da praça:

\begin{abstract}
- Nossa! Olhem para todos esses gringos! - Ela riu e levantou o braço, apontando para eles. - Está chovendo na minha horta! Vem aqui! Estou pronta! - Ela disse, cantarolando como se eles fossem franguinhos correndo desatentamente e que precisassem ser encurralados. Enquanto cantarolava, ela colocou uma perna na cadeira, formando um ângulo reto com os joelhos, e ventilou a virilha com sua mão, como se estivesse atraindo todos aqueles "pequenos franguinhos" em direção a sua vagina.
\end{abstract}

Blanchette (2015, p.171) afirma que "gringos, como estranhos, também contêm algo do que Lévi-Strauss rotulou como significante flutuante, no qual eles representam um valor indeterminado de significação”. O gringo pode ser mercurial e pode mudar com o tempo, até mesmo adotando algumas características da cultura do hóspede. Assim, gringos bons podem se tornar "mongers" e começar a tratar as prostitutas brasileiras como os homens brasileiros o fazem. Blanchette segue elaborando como o gringo se desenvolveu com o passar do tempo até o seu estado atual, como se fosse uma tela em branco na qual os indivíduos podem projetar o 
que eles quiserem de acordo com suas próprias ideologias. No caso da Copa do Mundo (e também das Olimpíadas), o gringo é meramente um bicho papão, porém é um bicho papão útil, pois permite que o governo, os cristãos evangélicos e grupos católicos, as feministas antiprostituição e outros decretem suas próprias agendas sob a fachada de um pânico moral. As significações projetadas na ideia do gringo revelam mais sobre as obsessões sexuais daqueles que fazem a projeção do que sobre a atual realidade da economia sexual. Existem certamente alguns gringos que pagariam por sexo com meninas menores de idade (e de qualquer idade), mas a maioria esmagadora das prostitutas viam os gringos da Copa do Mundo como presas e não como predadores. Isso era verdade não apenas na área ao ar livre perto do Balcony Bar em frente à FIFA Fan Fest - onde se pode esperar encontrar turistas sexuais acidentais tropeçando para fora da partida e se interessando pela festa na rua sem perceber que ali é o coração da prostituição de Copacabana - mas também dentro dos bordéis.

\section{GRINGOS NA CERCA}

Thaddeus Blanchette e eu nos sentamos em uma terma em Copacabana, usando roupões brancos e chinelos, bebericando caipirinhas e tomando notas. Essa era nossa tarefa do Observatório, pois apenas homens são permitidos nas termas e a maior parte dos pesquisadores da nossa equipe são mulheres. Termas são casas de banho com prostituição heterossexual no estilo dos bordéis. Uma sauna é a versão gay da terma (ver Mitchell, 2016c). Numa sauna pode haver garotos de programa (significando que trabalhadores sexuais estão disponíveis) ou não (significando que os clientes podem fazer sexo uns com os outros, de graça), mas uma terma sempre envolve a prostituição. O cliente usa uma pulseira e ao sair, paga uma taxa de entrada, aluguel do quarto, qualquer comida ou bebida que tenha consumido e o custo de um programa. Programas em um local de alto nível como este geralmente custam 300 reais, incluindo o quarto e a taxa de entrada. A casa pode ficar com até a metade deste valor. As mulheres acham isso aceitável, pois mesmo que elas consigam o mesmo valor ou até mesmo um pouco menos do que poderiam fazer na rua, aqui elas têm privacidade e também a segurança para lidar com a polícia, clientes ou outros elementos perigosos.

Esta terma em particular possui vários andares, o que é típico. Há uma sauna a vapor e uma sauna seca que somente os clientes utilizam. Existe um andar repleto de cabines, que estão disponíveis para alugar e fazer programas. Também há uma sala retangular com um bar completo em sua extremidade. Há assentos e pequenas mesas ao longo da periferia e há um DJ tocando club music. Este andar é reservado 
para dançar, mas, neste momento, apenas algumas mulheres se encontram nele. Quase todas as quarenta mulheres desta terma da Zona Sul são brancas e loiras, com cabelos tingidos (geralmente) e quimicamente alisados. Elas estão sozinhas, espalhadas nesse espaço, fazendo uma pequena dança que consiste em balançar a bunda. As mulheres vestem uma saia muito curta que sobe quando elas fazem isso, então, a maior parte da dança também envolve puxar a saia para baixo a cada segundo. Nos bancos há homens sentados e vestidos com roupões, conversando entre si e às vezes com as mulheres que se aproximam, paqueram com eles e, talvez, deixam o cliente pagar uma bebida (geralmente uma bebida não alcoólica, pois as mulheres invariavelmente mencionam que muitas não desejam as calorias e nem os problemas de saúde que uma noite bebendo sem parar pode ocasionar).

Duas mulheres se juntam a nossa mesa. Elas estão muito interessadas na pesquisa do Observatório e estão interessadas em aprender mais sobre o grupo de direitos das prostitutas, o Davida, que mencionamos. Elas nos aconselham a não falar muito alto sobre este assunto, pois o gerente daquela terma não gostaria que elas conversassem com organizações de profissionais do sexo. Algumas termas deram boas-vindas ao grupo Davida, mas esta não. Vimos um grupo de jovens gringos dos EUA entrarem no bar e se sentarem na frente de nossa mesa. Eles se sentam em uma linha perfeita, como quatro pássaros empoleirados numa cerca, suas mãos cuidadosamente apoiadas no colo. Todos concordamos que eles pareciam estar completamente apavorados, o que é uma graça.

Esses homens parecem ser recém-saídos da faculdade, com talvez 23 ou 24 anos. São todos brancos e bem cuidados, barbeados e com os cabelos arrumados. Eles puxam e arrumam seus roupões nervosamente, rindo sem jeito e sussurrando nos ouvidos uns dos outros enquanto assistiam as garotas na pista de dança. É como em um baile do ensino médio em um ginásio: meninos tímidos se escorando na parede, com medo de convidar uma garota para dançar. De repente, um velho homem negro que parece ter quase setenta anos sobe na pista de dança e começa a dançar habilmente um pouco de samba com as mulheres. Ele é tão bom que o bar inteiro olha para ele, extasiado. Uma mulher sorri com alegria, abandona sua dancinha e começa a realmente se mostrar. Eles alternam para algum outro tipo de dança de salão e o homem a faz girar. Durante vários momentos as pessoas aplaudem e se exaltam. Bárbara, uma das garotas que estava sentada conosco explica que ele é um cliente regular. Ele é um expatriado afro-americano e todas as mulheres o amam. Para elas, pouco importa se ele é velho ou se ele é negro. Ele é um gringo bom - charmoso, generoso, respeitador e um bom dançarino também. 
Após eles terminarem, os dois dançarinos foram sentar-se em um banco. Ninguém quer seguir esse ato. Nós continuamos a observar os meninos brancos. Uma das mulheres se aproxima e se senta, sussurrando no ouvido de um deles. Ele é o que primeiro entrou na sala e escolheu seus lugares e parece ser mais corajoso que seus amigos - pelo menos corajoso o suficiente para conversar com a prostituta. Após um minuto, ela faz uma careta e se afasta. Bárbara vai falar com essa prostituta para saber o que houve. Ela retorna e relata o ocorrido:

- Eles dizem que estão aqui apenas para olhar. Eles são apenas curiosos. Eles não querem programa. - Todos riem disso.

Depois de aproximadamente dez minutos, muitas outras mulheres chegam e logo ficam sabendo que os meninos gringos “só querem olhar". O jogo começa. As mulheres começam a torturar os meninos, fazendo a dança que faz a saia subir na cara deles, mordiscando suas orelhas e brincando com os cintos de corda dos seus roupões. Elas os provocam e se divertem às custas deles. O gringo líder é o primeiro a "subir", como dizem as mulheres, ou seguir com destino ao andar superior para um programa.

Uma vez que ele se foi, os outros garotos nem se mexem para preencher o espaço que ficou vazio. De algum modo, eles parecem se comprimir como se estivessem se amontoando para se protegerem. Outra mulher se aproxima e se senta onde o líder estava. Ela começa a agir no próximo cara. Ele tem ombros largos como um jogador de futebol americano. Percebo que ele tem um anel de casamento. Ele até brinca com ele, como se fosse algum tipo de expressão freudiana muito óbvia de culpa. Menciono para meus companheiros de mesa que ele parece ser tão jovem que não poderia estar casado há muito tempo. A mulher continua a mexer com ele. O garoto de ombros largos continua a enrubescer, continua a balançar a cabeça, continua recusando e continua afastando as mãos dela para longe dele. Porém, após cinco minutos, ela está puxando-o pelo braço, rebocando-o pelo salão como um pequeno rebocador arrastando um navio pesado. Para cima seguem, em direção à sua cabine.

O terceiro é ruivo e sardento. A própria Bárbara abandona nosso banco e o pega. Ela despenteia seus cabelos e sussurra em seu ouvido. Seja o que for que ela disse, funcionou, pois logo ele sai de mãos dadas com ela. Ele murmura algum tipo de pedido de desculpas para seu amigo, o qual acaba de abandonar no banco. Viro-me para o meu colega e digo " $5 \ldots 4 \ldots 3 \ldots$... mas nem chego a terminar. Uma mulher - uma das poucas que têm cabelos negros - vai em direção ao banco. Ela 
não diz uma palavra. Ela sequer o olha nos olhos. Simplesmente passa por ele sem parar, deslizando sua mão na dele enquanto caminha, e o leva para cima.

Algumas horas depois, meu colega e eu deixamos a terma e retornamos aos arredores do Balcony Bar, que estava fechado, para fazer algumas entrevistas com as mulheres que estavam trabalhando lá e para ver como andavam os negócios naquela noite. De repente, vejo quatro figuras se aproximando. Eles estão rindo e se abraçando, gritando, pulando e falando um com o outro. Surpreso, bato no ombro do meu colega - Olha! - É tudo o que consigo dizer. Nós observamos enquanto nossos quatro pequenos pássaros da cerca passam por nós como um trovão, extáticos. Podemos ouvir fragmentos da história enquanto eles se regalam falando de suas proezas durante o programa, mas agora sem medo e com bravata. Não temos como não imaginar como a versão das prostitutas se compararia com a deles, mas como as prostitutas sempre dizem, os detalhes dos programas ficam "entre quatro paredes, querido".

Apesar do fato de que nem a prostituição, nem o tráfico sexual, aumentaram significativamente durante a Copa do Mundo, a mídia dos EUA continuava a propagar notícias sensacionalistas tal como o Huffington Post, que declarou: "Crianças vendidas para sexo na Copa do Mundo por poucos dólares, pacotes de cigarros" (GOLDBERG, 2014). Enquanto isso, o Human Trafficking Search (um projeto da peculiarmente sombria Fundação OLP) declarou que,

no ano anterior à Copa do Mundo da FIFA, garotas de áreas pobres do Brasil começaram a desaparecer. Muitas das jovens mulheres foram sequestradas das favelas do Brasil por traficantes sexuais e foram levadas para as cidades onde aconteceria a Copa do Mundo da FIFA e seriam usadas para servirem aos trabalhadores que construíam os estádios de futebol (LiLlie, 2014).

Como evidência, eles utilizam uma história de um tabloide britânico que se refere a textos sem fontes, rumores infundados de segunda (ou possivelmente de terceira) mão de que a máfia russa estava traficando garotas para o Brasil e também trazendo escravas sexuais da África para o Brasil. Isto é curioso porque nossa equipe de cientistas sociais conduziu visitas regulares a dezenas dos locais estabelecidos, inclusive o que é frequentado pelos atuais operários no Rio de Janeiro e encontramos poucas mulheres que viajaram de qualquer lugar fora do Rio para a Copa e apenas uma que não era brasileira: uma peruana trabalhando numa terma de classe média, que disse que ela ganhava menos dinheiro trabalhando em Lima do que durante a Copa. 
Enquanto certamente há prostituição infantil no Brasil e a exploração sexual existe, as fantasias criadas pelos evangélicos e pelos grupos antiprostituição parece revelar muito mais sobre a vida íntima dos salvadores do que sobre as experiências das prostitutas diante da Copa do Mundo. O grupo evangélico Exodus Cry primeiramente declarou ter parceria com mais de 500 igrejas brasileiras durante a Copa e disse que eles "alcançaram 1.972 homens, mulheres e crianças exploradas". Entretanto, não fica claro o que "alcançar" significa. Eles também "treinaram mais de 1.539 voluntários internacionais em sensibilização e intervenção”. Fica ainda menos claro exatamente em que estes trabalhadores e sensibilizadores estavam intervindo, dado que havia quase salvadores o suficiente para cada um ter a sua própria pessoa explorada para "alcançar" (Exodus CRY, 2014). O Exodus Cry também postou uma citação inspirada sobre a falta de vítimas do tráfico sexual dizendo: "A pergunta que devemos nos fazer é a seguinte: Se os homens que os compram para o sexo podem encontrá-los para o sexo, por que não podemos?”. Acho que esses evangélicos responderam sua própria pergunta.

\section{CONCLUSÃO}

Os gringos têm um lugar especial na cultura carioca. Turismo é a alma da economia carioca e os gringos são uma constante presença para qualquer um que more no Centro ou na Zona Sul. Os cariocas podem achar os gringos exasperados, tolos, ofensivos, ingênuos, cosmopolitas ou mesmo desejáveis sexualmente. No entanto, as construções cariocas sobre o gringo não são as que dominaram a cobertura da mídia da Copa do Mundo, nem são aquelas que o governo tinha em mente quando começou a projetar campanhas publicitárias para o público. O Vaticano certamente não mostrou qualquer familiaridade com os sentimentos matizados do carioca em relação aos gringos quando utilizou a sua considerável influência para começar a assustar os brasileiros. Quando a filial brasileira do grupo feminista internacional Femen chegou e tomou o aeroporto no Rio de Janeiro, encenando protestos nus para chamar a atenção para a "exploração sexual" do turismo sexual, elas não estavam usando o entendimento das profissionais do sexo cariocas sobre os gringos, e sim uma posição ideologicamente forjada por feministas radicais internacionais. E quando grupos evangélicos dos Estados Unidos vieram a centenas de igrejas brasileiras para mostrar filmes horripilantes sobre o "tráfico sexual" em um esforço para "sensibilizar" sobre os milhares de gringos predadores que estariam supostamente chegando para levar as filhas do Brasil, eles não estavam usando as complexas compreensões do carioca sobre os gringos. 
Em vez disso, todos esses grupos projetam suas próprias fantasias, medos e preconceitos sobre a ideia do gringo. Fazendo assim, eles criam uma narrativa mitológica sobre o Brasil presumindo que as mulheres brasileiras são vulneráveis e que já estariam se tornando vítimas de homens estrangeiros e predatórios. Isso torna impossível qualquer ideia de agenciamento para mulheres brasileiras que vendem sexo, pois promove uma ideologia de moralizar forças neocoloniais que colocam todas as prostitutas na categoria de vítimas do tráfico. Ao fazê-lo, rejeita-se a autonomia do Brasil enquanto país onde a prostituição não é crime e se rende à visão de estrangeiros de um Brasil atrasado, incompetente e incapaz de proteger seus próprios cidadãos. Na verdade, as prostitutas do Rio acharam que os gringos que vieram durante a Copa e compraram sexo eram especialmente "gringos bons" que estavam suscetíveis ao jeitinho das prostitutas, que pagam o que é solicitado, que são educados e generosos e que não criam problemas. Longe de trazer homens grosseiros ou hooligans violentos, a Copa do Mundo trouxe (de acordo com a preocupação das prostitutas) talvez muitos fariseus que não queriam comprar sexo, mas os gringos que compraram eram os melhores tipos de gringo possíveis.

O período reacionário que descrevi - o qual podemos chamar de O Grande Pânico sobre os Gringos de 2014 - pode parecer relativamente banal. Quem se importa se estes gringos privilegiados estão sendo incompreendidos ou difamados? Meu propósito aqui não é instilar simpatia pelos gringos. Nem tenho como propósito criar algum tipo de "direitos dos homens" alegando que grupos de feministas radicais difamaram os gringos com seus estereótipos equivocados de hooligans ou da "lad culture ${ }^{5}$ ". Em vez disso, o que é importante compreender é que o pânico sobre a presença dos gringos em 2014 foi um pânico moral. Como a antropóloga feminista Gayle Rubin (1984) argumentou em seu ensaio canônico, Thinking Sex ("Pensando o sexo"), durante períodos de pânico moral em que forças conservadoras acreditam que a sexualidade é fundamentalmente pecaminosa, é possível que se aprovem alterações legislativas e se adotem outras ações que têm consequências a longo prazo, por restringir a liberdade e as escolhas sexuais dos “outros”, especialmente aqueles que já se encontram nas margens sexuais da sociedade (Rubin, 1984; conferir também LANCASTER, 2011). O pânico sobre os gringos também pode gerar esses tipos de consequências.

5 O termo "hooligans" é utilizado para descrever fãs de futebol barulhentos que têm mau comportamento, envolvendo-se em brigas e consumindo álcool em excesso. Já a expressão britânica "lad culture" é usada para descrever e justificar, de forma condescendente, o mau comportamento dos homens. 
Além do fechamento do Balcony Bar, a polícia também conduziu uma grande operação em um prédio onde dezenas de mulheres moravam e vendiam sexo em Niterói, semanas antes da Copa do Mundo. Durante esta incursão, eles bateram nas mulheres, roubaram todos os seus pertences e seu dinheiro e escolheram algumas mulheres para agredir sexualmente. Os membros do Observatório se encontraram e trabalharam com as mulheres para provir assistência. Quando uma destas mulheres denunciou esse crime, ela foi sequestrada, torturada com lâminas de barbear, e mostraram-lhe fotos dos seus filhos enquanto os sequestradores ameaçavam matá-la e a seus filhos ${ }^{6}$.

Os evangélicos e os grupos feministas antiprostituição não iriam perdoar tal operação, mas os seus medos e suas contribuições para criar o pânico sobre os gringos os fizeram cúmplices dessa ação. Aderir a uma ideologia de pânico em relação ao gringo permite que forças antiprostituição construam o gringo para justificar seu próprio moralismo imperial. Isto permite que campanhas de limpeza social e incursões de bordéis aconteçam nas chamadas zonas da luz vermelha. $\mathrm{O}$ pânico dirigido aos gringos possibilitou a apropriação de terras, a gentrificação de áreas em Copacabana e o abuso de mulheres que vendem sexo. Eliminaram-se os direitos dessas mulheres de ter proteção e segurança e se restringiram suas habilidades de livre locomoção em sua própria cidade. Na verdade, é uma ironia sinistra o fato de que as mitologias dos movimentos antitráfico acabariam por limitar a liberdade das mulheres. Fomentar esse pânico moral por causa dos grandes eventos esportivos do Rio teve como efeito a retirada dessas mulheres da cena sexual, a fim de limpar a cidade para que ela pudesse renascer sem pecados.

E, para finalizar, o local onde se encontrava o Balcony Bar reabriu tendo um novo proprietário e ainda em tempo para as Olimpíadas de 2016. Agora é um restaurante caro da orla, sofisticado e bem iluminado, sem uma puta sequer. E o nome desse restaurante chique? Imaculada. Concebida sem pecado, realmente...

\section{REFERÊNCIAS BIBLIOGRÁFICAS}

AJAm, Kashiefa. Trafficking of people, the Cup crisis that never was. IOL News, 17 de julho de 2010. Disponível em: http://bit.ly/108XioE. Acesso em: 26 de março de 2013.

Benevides, Carolina; LAvor, Thays; onofre, Renato; PINTo Anselmo. Aliciadores já atuam em cidades da Copa do Mundo. O Globo, 27 de abril de 2014. Disponível em: http://

6 Para uma análise completa deste caso, ver Blanchette; Mitchell; MurRaY, 2015; conferir, também, Mitchell, 2016b. 
oglobo.globo.com/brasil/aliciadores-ja-atuam-em-cidades-da-copa-do-mundo12310760\#ixzz3dik5oJDN. Acesso em: 26 de maio de 2016.

Blanchette, Thaddeus Gregory. “Fariseus' e 'gringos bons': masculinidade e turismo sexual em Copacabana”. In: Assis, Glaucia de Oliveira; olivar, José Miguel Nieto; PISCITELLI, Adriana (org.). Gênero, sexo, amor e dinheiro: mobilidades transnacionais envolvendo o Brasil. Pagu, Núcleo de Estudos de Gênero: Campinas, 2012, p. 57-102. “'Almost a Brazilian': Gringos, Immigration and Irregularity in Brazil." In: ACARAzo, Diego; wiEsbrock, Anja (org.). Global Migration: Old Assumptions, New Dynamics. Santa Barbara, Praeger: 2015, p.167-194.

Blanchette, Thaddeus Gregory; Silva, Ana Paula. "Nossa Senhora da Help: sexo, turismo e deslocamento transnacional em Copacabana”. Cadernos Pagu, n. 25, p. 249-280, 2005 .

"Sympathy for the devil: Pimps, agents and third parties involved in the sale of sex in Rio de Janeiro." In: Third Party Sex Work and "Pimps" in the Age of Anti-Trafficking. Springer, (forthcoming) 2017.

Blanchette, Thaddeus Gregory; mitchell, Gregory; MURRAY, Laura. Discretionary Policing, or the Lesser Part of Valor: Prostitution, Law Enforcement, and Unregulated Regulation in Rio de Janeiro's Sexual Economy. Criminal Justice and Law Enforcement, v. 7. No prelo.

Borges, Waleska. 2012. Três pessoas são presas na Zona Sul acusadas de incentivar a prostituição. O Globo, 15 de junho de 2012. Disponível em: http://oglobo.globo.com/rio/ tres-pessoas-sao-presas-na-zona-sul-acusadas-de-incentivar-prostituicao-5213176. Acesso em: 26 de maio de 2016.

ExodUs CRY. “ALL EYES ON BRAZIL”, 2013. Disponível em: http://exoduscry.com/blog/ all-eyes-on-brazil/. Acesso em: 26 de março de 2013.

"Liberdade", 2014. Disponível em: http://exoduscry.com/liberdade/. Acesso em: 19 de fevereiro de 2016.

. "Exodus Cry", Facebook, 2015. Disponível em: https://www.facebook.com/ exoduscry. Acesso em: 19 de fevereiro de 2016.

FARLEY, Melissa. "Bad for the body, bad for the heart": Prostitution harms women even if legalized or decriminalized. Violence Against Women, v. 10, n. 10, p. 1087-1125, 2004. GLOBALALLIANCE AGAINSTTRAFFic In WOMEN. What's the Costof a Rumor?: A Guide to Sorting out the Myths and the Facts About Sporting Events and Trafficking. Bangkok, 2011. Disponível em: http://www.gaatw.org/publications/WhatstheCostofaRumour.11.15.2011.pdf. Acesso em: 19 de fevereiro de 2016.

GoldBERG, Eleanor. Children Sold For Sex At World Cup For Few Dollars, Pack Of Cigarettes. Huffington Post, 12 de junho de 2014. Disponível em: http://www.huffingtonpost. 
com/2014/o6/12/world-cup-child-prostitution_n_5474716.html. Acesso em: 19 de fevereiro de 2016.

JefFreys, Sheila. The Idea of Prostitution. Melbourne, Spinifex: 1997.

Kulick, Don. Causing a Commotion: Public Scandal as Resitance Among Brazilian Transgendered Prostitutes. Anthropology Today, v. 12, n. 6, p. 3-7, 1996.

LANCASTER, Roger. Sex Panic and the Punitive State. University of California Press, Berkeley: 2011.

LiLLIE, Michelle 2014. Sex Trafficking at the FIFA World Cup in Brazil. Human Trafficking Search, 14 de julho de 2014. Disponível em: http://humantraffickingsearch.net/wp/ sex-trafficking-at-the-fifa-world-cup-in-brazil/. Acesso em: 19 de fevereiro de 2016.

Mickelwait, Laila. Myth vs Fact: 6 Common Myths about Prostitution and the Law. Exodus Cry, 24 de março de 2015. Disponível em: http://exoduscry.com/blog/general/ myth-vs-fact-6-common-myths-about-prostitution-and-the-law/. Acesso em: 19 de fevereiro de 2016.

Mitchell, Gregory. "40,00o Missing Girls: Fallacious Spectacle, Unruly Sexual Politics, and Police Violence in Rio de Janeiro”. Brasiliana: Journal of Brazilian Studies, 2016a. No prelo.

. Evangelical Ecstasy Meets Feminist Fury: Sex Trafficking, Moral Panics, and Homonationalism during Global Sporting Events. GLQ, v. 22, n. 3, p 325-358, 2016b. . Tourist Attractions: Performing Race \& Masculinity in Brazil's Sexual Economy. Chicago: University of Chicago Press, 2016c.

OFFicial VATICAN NETWORK. Play for Life: Campaign against human trafficking in view of the World Cup, 20 de novembro de 2013. Disponível em: http://www.news.va/en/news/ americabrazil-play-for-life-campaign-against-human. Acesso em: 19 de fevereiro de 2016.

Phillips, Tom. Rio nightclub closure leaves prostitutes Helpless. The Guardian, 17 de agosto de 2009. Disponível em: http://www.theguardian.com/world/2009/aug/17/ rio-help-nightclub-closure. Acesso em: 26 de maio de 2016.

RosA, Renata. Vivendo um conto de fadas: Ensaio sobre cor e "fantasia" entre mulheres cariocas e homens estrangeiros. Dissertação (Mestrado) - Universidade Federal do Rio de Janeiro. Instituto de Filosofia e Ciências Sociais. Programa de Pós-Graduação em Antropologia e Sociologia, Rio de Janeiro, 1999.

Rubin, Gayle. "Thinking Sex: Notes for a Radical Theory of the Politics of Sexuality." In: vance, Carole (org.). Pleasure and Danger. Nova Iorque: Routledge, 1984.

States of Contradiction: Twelve Ways to Do Nothing about Trafficking While Pretending To. Social Research: An International Quarterly, v. 78, n. 3, p. 993-948, 2011. 
Verdade Gospel. ONG alerta para explosão da exploração sexual em sedes de Copa. Verdade Gospel, 24 de março de 2014. Disponível em: http://www.verdadegospel. com/ong-alerta-para-explosao-da-exploracao-sexual-em-sedes-de-copa/. Acesso em: 19 de fevereiro de 2016.

VerdéLIO, Andreia. Campanha contra exploração sexual durante a Copa é lançada em Brasília. Agência Brasil, 2014. Disponível em: http://agenciabrasil.ebc.com.br/ direitos-humanos/noticia/2014-03/campanha-contra-exploracao-sexual-emgrandes-eventos-e-lancada-no. Acesso em: 19 de fevereiro de 2016.

Weitzer, Ron. "Sex Trafficking and the Sex Industry: The Need for Evidence-Based Theory and Legislation". Journal of Criminal Law and Criminology, v. 101, n. 4, p. 13371370, 2011.

Recebido para publicação em: 25/08/2016. Aceito para publicação em: 01/10/2016. 